\title{
A PÜTHAGORASZI KÖZÉPARÁNYOSOK JELENTŐS TULAJDONSÁGAI ÉS SZEREPÜK AZ ÉPÍTÉSZETBEN
}

\section{THE IMPORTANT PROPRIETIES OF PYTHAGOREAN MEANS, AND ITS ROLE IN THE ARCHITECTURE}

\author{
ifj.Orbán György \\ Erdélyi Múzeum-Egyesület, 400009 Kolozsvár/Cluj-Napoca Napoca/Jókai u. 2-4, \\ orban@esvvv.com
}

\begin{abstract}
The scope of the paper is to present the proprieties of the Pythagorean means, and to highlite its role in the anthic thinking based architecture. The paper present based on examples, and in concrete arithmetic way, the role and use the same means system thinking, in architecture and space modeling. The means make possible a new way of analizing the space modeling, and make possible to understand completly new relations in architectural history and theory.
\end{abstract}

Keywords: means, proportion, architecture

\section{Összefoglalás}

A dolgozat célja a püthagoraszi középarányosok tulajdonságainak a bemutatása és az antik gondolkodású építészetben betöltött szerepük kiemelése. A dolgozat példákkal és konkrétan, számszerüen, mutatja be egyazon középarányos gondolkodás építészetben, téralkotásban betöltött szerepét, használatát. A középarányosok a téralkotás új tanulmányozását és teljesen új összefüggések megértését teszik lehetővé az építészettörténetben és -elméletben.

Kulcsszavak: középarányosok, arányok, épitészet

\section{Az „első három” középarányos- tapasztalat}

Két pozitív számot a és $b$, ha $a<b$, öszsze lehet hasonlítani abból a szempontból, hogy az egyik mennyivel nagyobb mint a másik (ez a b - a különbség), vagy azzal, hogy az egyik hányszorosa a másiknak, ez a b/a arány, amit a görögök ,logosz”-nak neveztek.

Természetesen tevődött fel a kérdés, hogy két adott $a<b$ valós szám esetén melyik az az $m$ szám, melyre az $b-m=m-a$ vagy az $\frac{b}{m}=\frac{m}{a}$ egyenlőség teljesül. Az első esetben ez az érték az $m=\frac{a+b}{2}=M 1(a, b)$ melyet az a és b számtani (vagy aritmetikai) középarányosának (vagy közepének) nevezünk Ezt a kérdésfelvetést szavakban - a kor gondolkodásának megfelelően - is meg lehet fogalmazni. Platón szavaival a számtani közép: „ugyanazzal a számmal haladja meg az egyik kültagot, mint amennyivel haladja öt meg a másik" [1:332]. A második esetben pedig ez az $m=\sqrt{a b}=M 2(a, b)$ szám, az a és b mértani (geometriai) középarányosa (közepe). (Ennek szavakban történő megfogalmazása: melyik az a szám $(m)$, amely annyiszor 
haladja meg $a$-t, amennyiszer $b$ haladja meg öt $(m)$ ?) Ugyancsak logikus az m-et az $\frac{b-m}{b}=\frac{m-a}{a}$ aránypárból keresni. A kapott $m=\frac{2 a b}{a+b}=M 3(a, b)$ az $a$ és $b$ harmonikus középarányosa.

\section{A babiloniai "gyökvonás" algo- ritmusa (kb. Kr.e. 1800) - gya- korlat}

Ó-Babilonban Kr.e. 1800-ban nagy pontossággal aritmetikailag meg tudták határozni egy négyzet átlójának a hosszát. A gyökvonásra, szavakba foglalt recept gyanánt, [2:23] kezdetleges eljárással, algoritmussal rendelkeztek. [3:28] Az eljárás lényege:

0 . tetszőleges első becslés a közelítésre $x_{0}<\sqrt{a}$;

1. a becsült érték segítségével a gyök a közelítő érték és a szám/közelítő érték között van, így két korlát közé került. $x_{0}<\sqrt{a}<a / x_{0}$ (ha $x_{i}>\sqrt{a}>$ $a / x_{i}$ akkor is maradnak a korlátok);

2. az új közelítő értéknek a két korlát számtani közepét vették és fojtatták a 1. pont szerint

$$
x_{1}=\frac{\mathrm{x}_{0}+\mathrm{a} / \mathrm{x}_{0}}{2} .
$$

Az YBC 7289 -es kőtábla [2:23] tanúsága szerint

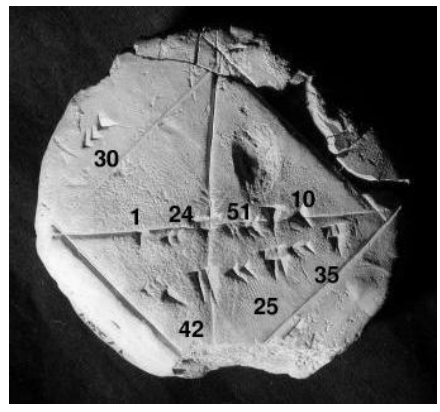

1. ábra. Az YBC 7289 kötábla [2:23] a gyökvonás algoritmusa alapján a $\sqrt{2}$ értékét $1.4142 \ldots$ megközelítőleg 8 milliomod, azaz 0.0000008 eltéréssel határozták meg (1.táblázat).[3:27][4:15-17]

1. táblázat. Gyökvonás algoritmusának rekonstrukciója

\begin{tabular}{|c|c|c|c|}
\hline Tábla érték & Jelentés & J. Érték & Szám \\
\hline 1,0000000 & & 1,0000000 & 1,0000000 \\
\hline 24,0000000 & $1 / 60$ & 0,0166667 & 0,4000000 \\
\hline 51,0000000 & $1 /(60 * 60)$ & 0,0002778 & 0,0141667 \\
\hline 10,0000000 & $1 /(60 * 60 * 60)$ & 0,0000046 & 0,0000463 \\
\hline Összesen & & & 1,4142130 \\
\hline Gyök 2 & & & 1,4142136 \\
\hline Eltérés & & & 0,0000006 \\
\hline
\end{tabular}

\section{Moszkvai pappirusz - Héron-féle középérték (kb. Kr.e.1800)- az absztrakció}

Ha $\mathrm{x}$ és y két pozitív szám, akkor a $\mathrm{h}=\frac{\mathrm{x}+\sqrt{\mathrm{xy}}+\mathrm{y}}{3}$ számot Héron-féle középértéknek nevezik.

Ennek mértani jelentése: ha x és y csonka gúla két alapjának területe, akkor a $\mathrm{h}$ az alapokkal párhuzamos azon síkmetszet területe, mely a gúlát két egyenlő térfogatú testre bontja fel.

Howard Eves szerint a Heron féle közepet már Kr.e. 1800 előtt ismerték. A moszkvai papiruszon szerepel egy probléma (14. számú), melyben numerikus feladatként egy piramisépítésnél használatos, elvégzett számítás van leírva. A csonka gúla térfogatának meghatározására leírt képlet a síkbeli trapézanalógia alapján, tapasztalati és intuitív módon alakult ki. A trapéz területének meghatározására az alapok számtani középarányosa volt megfelelő. A térbeli analógia szerint a csonka gúla alapjainak számtani közepe nem adott helyes eredményt (Ó-Babiloni analógia), az egyiptomiak azonban empirikus matematikai szemléletük szerint eljutottak a helyes formulához, ami alapján a Héron-féle középpel pontosan meg tudták határozni a csonka gúlák térfo- 
gatát. Eric Temple Bell szerint ez az indukció nagyobb eredménye az egyiptomiaknak mint maguk a piramisaik, a maguk fizikai valóságában és így a Héron-féle közép felfedezését a legnagyobb egyiptomi piramisnak nevezte. [5:11-13]

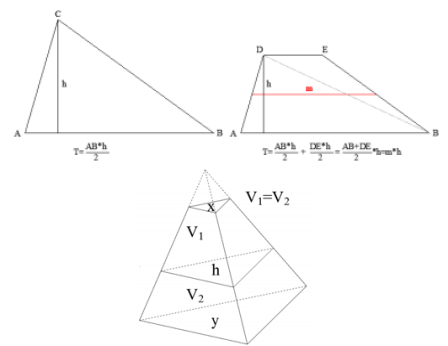

2. ábra. A Héron-féle középarányos geomeriai képe (jobbra)

A Héron-féle közép ugyan nem püthagoraszi középarányos, ám a gondolkodás és megalkotás logikája alapján ismertetése fontos, épp azért, hogy rávilágítson, milyen fontos szerepet töltött be a középarányos gondolata az ókorban.

\section{Püthagorasz és a püthagoreusok}

Püthagoraszról tudjuk, hogy járt Egyiptomban és Babilonban is. Ezen utazásai alatt elsajátíthatta az ott ismert matematikai tudást, így ismerte legalább a három: (számtani (M1), mértani (M2) és szembenálló, majd később harmonikusnak (M3) nevezett) középarányt. [2:78-80]

\subsection{A szabályos testek - az abszt- rakt harmónia}

A püthagoreusok, sőt előttük a babilóniaiak is észrevették (3.ábra), hogy a kocka éleinek (E, lapjainak (L) és csúcsainak (Cs) száma között a $C s=\frac{2 \cdot L \cdot E}{L+E}=\frac{2 \cdot 6 \cdot 12}{6+12}=8$ összefüggés igaz, és ugyanez teljesül más szabályos poliéder esetén is, vagyis a csúcsok száma az élek és lapok számának harmonikus középarányosa. „Íme - mondták már az ókorban -, a szabályos testekben rejlő harmónia, tükröződik a számok harmóniájában." [2:82].

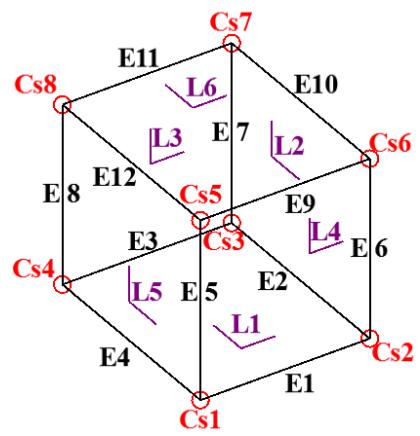

3. ábra. A kocka csúcsa, élei és lapjai

\subsection{Középarányosok a püthagora- szi zenében - az absztrakció al- kalmazása}

Püthagorasz egy kifeszített húr pengetésének tanulmányozása nyomán fogalmazta meg a legtisztábban összecsengő hangokat (konszonanciákat). Ehhez egy monochordnak (a monochord helyett vízzel telt poharak vagy kalapácsok is lehetségesek) nevezett egyhúrú hangszert használt.

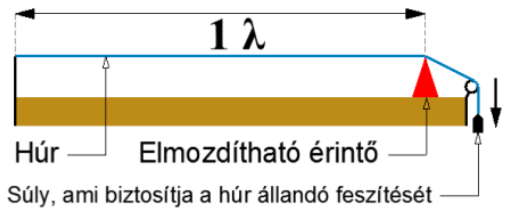

\section{4. ábra. Monochord}

Egy adott hosszúságú húrt megpengetve meghatározza a hozzá tartozó hangmagasságot. A monochordnak van egy elmozdítható érintője, mellyel változtatható a húr hossza. Ahogy csökken a húrhossz, úgy nő a rezgő húr által kibocsátott hang magassága. $\mathrm{Az} \quad f$ frekvencia (a hangmagasság) a $\lambda$ hullámhosszal (húrral) fordítottan arányos. A hullám $v$ sebességének és a $\lambda$ hullámhosszának a hányadosa az $f_{1}=\frac{v}{\lambda}$ frekvencia. Így ha a 
$\lambda$ hullámhossz a felére csökken, a frekvencia a duplájára nő: $f_{8}=\frac{v}{\frac{\lambda}{2}}=\frac{2 \cdot v}{\lambda}=2 \cdot \frac{v}{\lambda}$, vagyis a hang egy oktávval lesz magasabb.

A monochord kezdeti húrhossza az alaphangot bocsátja ki. A húrt a felére csökkentve kétszer olyan magas hangot hozunk létre, mint az alaphang, ezt a hangközt oktávnak nevezik. A húrhosszat 3/4-ére csökkentve 4/3-szór magasabb hangot, azaz kvartot (alaphaghoz viszonyítva) hozunk létre. $\mathrm{Az}$ eredeti húrhosszat 2/3-ára rövidítve 3/2-szer magasabb hangot kapunk, ami az alaphanghoz viszonyítva kvint távolságra van.

Püthagorasz észrevette, hogy a legszebben összecsengő hangok az alaphang és a kvint $1:(2 / 3)$, az alaphang és a kvart 1:(3/4), valamint az alaphang és oktávja 1:(1/2) távolságra levő hangok, vagyis: a kvart, kvint és oktáv hangközök. A fentiek alapján a püthagoreusok megfogalmazták, hogy kis egész számok $(1,2,3,4)$ arányaival lehet a hangközöket jellemezni és meghatározni. [2:81-82] Ugyanekkor észrevették, hogy a hangok arányai, a szépen összecsengő hangközök középarányosokkal is meghatározhatók. Az alaphang (X Hz) és oktávja (2X Hz) közötti számtani középarányossal meghatározott hangmagasság $(3 / 2 \mathrm{X} \mathrm{Hz})$ a kvint, a harmonikus középarányossal meghatározott (4/3 X Hz) a kvart.

A szabályos testekben tükröződő számok harmóniája így a zenei skálákra is érvényesnek bizonyult. Püthagorasz működése nyomán elfogadottá vált, hogy az oktávot a kvint és a kvart (számtani és harmonikus közép) segítségével lehet felosztani (A kvint és kvart általi felosztást nevezték rögzített hangközöknek, míg köztük helyezkednek el a „mozgó” hangközök, amiknek a kiosztása a görög zeneelmélet egy központi feladatává vált.)

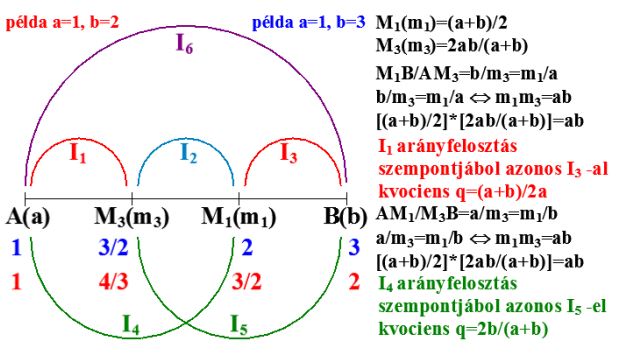

5. ábra. Az oktáv felosztása Püthagorasz szerint, középarányosokkal

Püthagorasz zeneelmélete, de még inkább a szépségről alkotott absztrakt modell hatása meghatározó volt az utána következő évezredekben. Ennek talán legszebb pédája a Vatikánban levő Athéni iskola freskója, ahol Rafaello ugyanezt az ábrát festi meg Püthagorasz atribútumaként.

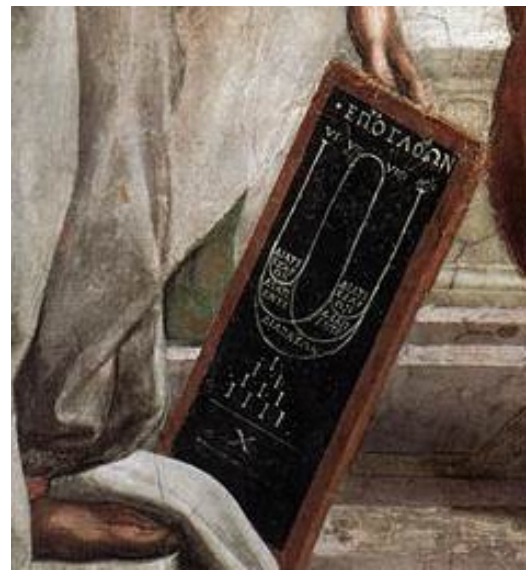

6. ábra. - Raffaello Sanzio: Athéni iskola (részlet: Püthagorasz zenét oktat), 1509, Vatikáni Múzeum, fresko

\section{A déloszi oltárkő - a kór prob- lémái és gondolkodása}

A déloszi oltárkő megkétszerezésének nevezetes problémája is a folytonos arányok problematikájára vezethető vissza. (Délosz szigetén az istenek azt kívánták az emberektől, hogy az ott álló kocka alakú oltárkövet kettőzzék meg, és akkor elmúlik 
a városban dühöngő pestisjárvány. A kőfaragók azonban nem tudták megmondani, sem megszerkeszteni, hogy mekkora a kétszer nagyobb köbtartalmú kocka éle, így nem is tudták kifaragni. [2:101] Hippokratész (Kr.e. 450 körül) általánosította a síkban megoldandó négyzetkettőzés feladatát, ahol egy négyzethez egy kétszer akkora területü négyzetet kell szerkeszteni, aminek megoldása egy mértani középarányossal mint aránylánccal lehetséges $\mathrm{a}: \mathrm{x}=\mathrm{x}: 2 \mathrm{a}$, ahonnan $\mathrm{x}^{2}=2 \mathrm{a}^{2}$.

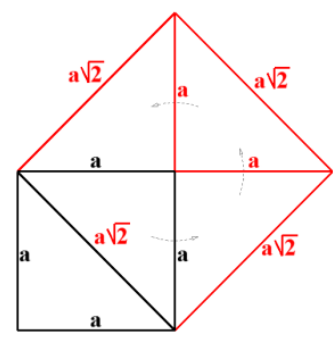

7. ábra. Négyzetkettözés

Térben, úgy gondolta, nem egy, hanem két középarányost kell a két szélső érték közé iktatni. Ezzel az egyenletrendszerrel pedig aritmetikailag kifejezte, arányláncként meghatározta a kockakettőzés megoldását: $\mathrm{a}: \mathrm{x}=\mathrm{x}: \mathrm{y}=\mathrm{y}: 2 \mathrm{a}$, ahonnan $\mathrm{x}^{2}=\mathrm{ay}$ és $\mathrm{xy}=2 \mathrm{a}^{2}$, vagyis $y=\frac{x^{2}}{a}$, amit beírva a második egyenletbe: $x^{3}=2 a^{3}$. A szerkesztéssel nem boldogult. [2:106]

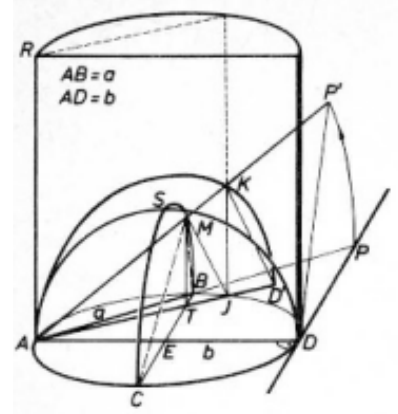

8. ábra. Kockakettözés[2]
Arkhütasz (Kr. e. 428-365) azonban eredményes matematikusként a kockakettőzés hippokratészi megoldása nyomán egy káprázatos térbeli szerkesztést hozott létre. [2:114]

A fenti példák alapján jól látszik, hogy a középarányosok fogalma a kor alapproblémáinak megoldásában fontos szerepet játszott.

\section{Platón - középarányosok mint világot formáló gondolat}

A matematikában majd zenében kialakult középarányosokat - mint a világ harmóniájának szabályait - Platón (Kr.e. 427347) foglalta össze és emelte filozófiájában méltó magasságra.

A középarányosokat mint arányláncokat a négy öselem összekapcsolására használta fel. Timaiosz címü müvében leírja a világ megalkotásának történetét. A világot tüzböl és földből formálták. Kettőjüket egy köztük levő kötelék foglalja egységbe. [1:328-329] Összetartó láncként az arányosságot említi. Itt játszik szerepet a folytonos aránylánc, valamint a vele egyenértékü mértani középarányosok. Taylor rávilágít, hogy , ,... a tüz és a föld azonban térbeli kiterjedéssel rendelkeznek, három dimenzióban léteznek, igy nem egy (mint a négyzetkettőzésnél), hanem két(mint a kockakettözésnél) középarányost kell használnunk. Erre a szerepre pedig a levegö és a víz kínálkozik". [6:617] A tüz úgy aránylik a levegőhöz, mint a levegő a vízhez és a víz a földhöz: $\frac{t_{u ̈ u ̈}}{\text { levegö }}=\frac{\text { levegö }}{\text { viz }}=\frac{\text { viz }}{\text { föld }}$ [1:329] Ugyancsak Taylor említi, hogy „a kocka megkétszerezésének nevezetes problémájára történik utalás". [6:617] Ugyanott megfogalmazza, hogy a mértani közép felhasználásával a püthagoreus matematika összekapcsolódhat a négy „gyökér” empedoklészi doktrínájával. [6:617] Taylor nyomán megállapíthatjuk, hogy Platón a Timaioszban a középarányosokat aránylánc formában használta a 
világ négy elemből való alkotásának szerkesztő elveként.

A Timaioszban szerepel a világtestet átjáró világlélek leírása is. A világlélek rendszerének megalkotásában Platón, a középarányosokat használja fel. A világlélek alkotóelemeinek leírását nem részletezem[1:331-333][6:617], hanem annak Timaiosz szerinti felosztásában mutatom be a középarányos rendszer felhasználását. Intervallumokat képez az 1,2,4,8 és az 1,3,9,27 mértani haladványok egymást követő tagjai között. A kétszeres és háromszoros intervallumokban két középarányost (számtanit és harmonikust) helyez el. Ez a származtatás lényege.

Az eredeti sorozatok tagjait, a származtatott középarányosokkal sorrendbe írja. Az így keletkezett 4/3 intervallumokat kitölti a 9/8 arányaival úgy, hogy a fennmaradó részek 256/243 legyenek. A leírás a püthagoraszi skála leírása 4 egész és 5/27-ed oktáv erejéig. Az így nyert számok - a püthagoraszi skála hangjainak megfelelően, hangonként - 2-es kvóciensü mértani haladványoknak felelnek meg, vagy zenei terminusokkal oktávonként épülnek egymásra. (Az így megalkotott középarányos rendszer vagy „,készítmény” Platónnál a csillagászat alappillérévé is vált. A középarányosokkal átitatott pályákon keringenek az égitestek, és együttállásuk határozza meg a dolgok rendjét és idejét. [1:333-339])

$\mathrm{Az}$ oktávok egymásra épülését így az 1,2,4,8 mértani sorozat (a mértani sorozat vagy haladvány, egyben arányláncként is felfogható, jelen esetben: $1 / 2=2 / 4=4 / 8=\ldots$ ) fejezi ki. Ez az aránylánc nem más mint a mértani középarányosok fordított alkalmazása. Egy másik müvében az Epinomisz-ban megtudjuk - egyben a hosszúság, terület és térfogat arányait is kifejezi. Taylor szavaival „mondhatjuk tehát, hogy a 2:1 arány, ennek hatványai, valamint az egyes tényezők között meghatározható közepek a ter- mészet végső titkáról lebbentik fel a fátylat (990a-991b, Epinomisz,Plato)" [6:695].

Platón az általa leírt világkép rendező elveként határozta meg a középarányosok rendszerét, az arányosság ideáját. A számokban, a szabályos testekben, a zenében, a világot alkotó elemek egymáshoz való viszonyában és magát a világot átható és szabályozó lélekben látta meg a természet végső titkát, a világot formáló gondolatot és az örök harmóniát, melyet a középarányosok felhasználásával konkrétan le is írt.

A fentiekből kitünik, hogy az ókori görög gondolkodásban milyen fontos szerepet töltöttek be a középarányosok.

\section{Püthagoraszi középarányosok - az arányosság képletei}

Eudoxosz (Kr.e. 395-337) - Platón és Arkhütasz tanítványa - a Püthagorasz által ismert három középarányoson kívül másik hármat is leírt. [7:226-227] Hisher a Cantor által közölt, [7:227] Boyer által átalakított [3:56] forma szerint a következő középértékeket (mezotéták, azaz középen állók) tulajdonítja Eudoxosznak: [4:25] kontraharmonikus közép:

- M4: $\frac{m-a}{b-m}=\frac{b}{a}, 1$. kontramértani közép;

- M5: $\frac{m-a}{b-m}=\frac{m}{a}, 2$. kontramértani közép;

- M6: $\frac{m-a}{b-m}=\frac{b}{m}, 0<\mathrm{a}<\mathrm{m}<\mathrm{b}$.

A középarányosok tanulmányozása és használata így kezdett el bővülni.

Eratosztenész (Kr.e. 276-196) a Peri mezotéton címü müvében a középértékek elméletével foglalkozott (a mü nem maradt fenn, csak Papposz utalásai nyomán ismerjük létezését). [2:252] A középértékekről készült - valószínűleg átfogó - írás, mely a görög tudósok számára hozzáférhető és ismert lehetett, nem maradt ránk, de ez még nem ok arra, hogy a benne levő tudást fel ne használták volna a következő századokban. 
Nicomachus (Kr.u. 100 körül) megemlíti, hogy az első három középarányost már Püthagorasz elött ismerték. A következő hármat Arisztotelész és Platón koráig írták le a „tanítványok” (Platón tanítványa volt Arkhütasz, az ő tanítványa pedig Eudoxus, aki vélhetően a fent nevezett három középarányost leírta) és így együtt említi azt a hat középarányost, amit a „régi írók” hagyományához társítottak [8:283]. További négy az előzőekkel egyazon logikát követő középarányosról számol be, ami nem szerepelt a régiek műveiben, de bizonyosnak véli, hogy ismertek voltak, és használták őket [8:283-284]. Érdemes megjegyezni, hogy 10 középértéket Nichomachus
[8:257-259], vele azonos 9-et Pappus [9:87] is ismert, és még 1-et, így összesítve mind a 11 középértéket ismerték.

Ha $\mathrm{x}<\mathrm{m}<\mathrm{y}$ három pozitív szám és $\mathrm{H}=$ $\{\mathrm{b}-\mathrm{a}, \mathrm{m}-\mathrm{a}, \mathrm{b}-\mathrm{m}\}, \mathrm{J}=\{\mathrm{a}, \mathrm{m}, \mathrm{b}\} \quad$ számokból alkotott halmazok, akkor ennek elemeiből több olyan aránypár képezhető, melyek egy-egy $m$ középértéket határoznak meg. Az eljárást kombinatorikusan leírva $\mathrm{A}, \mathrm{B}$ a H-ból és C,D a J-ből egy-egy tetszőlegesen választott elem. Ekkor $\mathrm{M}$ középértéket meghatározó képleten az A / $\mathrm{B}=\mathrm{C} / \mathrm{D}$ aránypárt értjük, amiből 11 különböző létezik. A középarányosok táblázatban összefoglalva a következők [4:28]:

2. táblázat. Püthagoraszi középarányosok

\begin{tabular}{|c|c|c|c|c|}
\hline sorszám & $\begin{array}{l}\text { meghatározó } \\
\text { aránysor }\end{array}$ & középérték & elnevezés jelölés & $\begin{array}{l}\text { egy-egy példa } \\
\text { egész számokban }\end{array}$ \\
\hline 1. & $\frac{m-a}{b-m}=\frac{a}{a}$ & $m=\frac{a+b}{2}$ & $\begin{array}{c}\text { számtani közép } \\
M_{1}(a, b)=A(a, b)\end{array}$ & $M_{1}(1,3)=2$ \\
\hline 2. & $\frac{m-a}{b-m}=\frac{a}{m}$ & $m=\sqrt{a \cdot b}$ & $\begin{array}{c}\text { mértani közép } \\
M_{2}(a, b)=G(a, b)\end{array}$ & $M_{2}(1,3)=2$ \\
\hline 3. & $\frac{m-a}{b-m}=\frac{a}{b}$ & $m=\frac{2 \cdot a \cdot b}{a+b}$ & $\begin{array}{c}\text { harmonikus közép } \\
M_{3}(a, b)=H(a, b)\end{array}$ & $M_{3}(3,6)=4$ \\
\hline 4. & $\frac{m-a}{b-m}=\frac{b}{a}$ & $m=\frac{x^{2}+y^{2}}{x+y}$ & $\begin{array}{l}\text { kontraharmonikus közép } \\
\qquad M_{4}(a, b)\end{array}$ & $M_{4}(3,6)=5$ \\
\hline 5. & $\frac{m-a}{b-m}=\frac{m}{a}$ & $m=\frac{b-a}{2}+\sqrt{\left(\frac{b-a}{2}\right)^{2}+a^{2}}$ & $\begin{array}{l}\text { kontramértani közép } 1 . \\
\qquad M_{5}(a, b)\end{array}$ & $M_{5}(2,5)=4$ \\
\hline 6. & $\frac{m-a}{b-m}=\frac{b}{m}$ & $m=-\frac{b-a}{2}+\sqrt{\left(\frac{b-a}{2}\right)^{2}+b^{2}}$ & $\begin{array}{l}\text { kontramértani közép } 2 . \\
M_{6}(a, b)\end{array}$ & $M_{6}(1,6)=4$ \\
\hline 7. & $\frac{b-a}{m-a}=\frac{b}{a}$ & $m=b-\frac{(b-a)^{2}}{b}$ & $M_{7}(a, b)$ & $M_{7}(6,9)=8$ \\
\hline 8. & $\frac{b-a}{b-m}=\frac{b}{a}$ & $m=a+\frac{(b-a)^{2}}{b}$ & $M_{8}(a, b)$ & $M_{8}(6,9)=7$ \\
\hline 9. & $\frac{b-a}{m-a}=\frac{m}{a}$ & $m=\frac{a}{2}+\frac{1}{2} \cdot \sqrt{4 \cdot a \cdot b-3 \cdot a^{2}}$ & $M_{9}(a, b)$ & $M_{9}(4,7)=6$ \\
\hline 10. & $\frac{b-a}{b-m}=\frac{m}{a}$ & $m=\max \{b-a, a\}$ & $M_{10}(a, b)$ & $\mathrm{M}_{10}(3,8)=5$ \\
\hline 11. & $\frac{b-a}{b-m}=\frac{b}{m}$ & $m=\frac{y^{2}}{2 \cdot b-a}$ & $M_{11}(a, b)$ & $M_{11}(3,6)=4$ \\
\hline
\end{tabular}




\section{Középarányosok a filozófiai gondolkodásban - a szépség mértéke}

A középarányosokat eredeti aránypár mivoltuk miatt és a fentiek alapján méltán ilethetjük és társíthatjuk az arányossággal.

Már az ókorban a szépség mértékét az arányosságban látták. Ez a gondolat végigkísérte az emberi történelmet és a müvészet racionális megítélését is, az ókortól, a humanizmus koráig mindenképp.

Szent Bonaventura igen találóan fogalmazza meg az arányosság és szépség elengedhetetlennek tartott kapcsolatát: „Minthogy tehát minden dolog szép és valamiképpen gyönyörködtető; s a szépség és gyönyörüség nem lehetséges arány (proportio) nélkül; az arány pedig elsősorban a számokban rejlik: szükséges, hogy minden dolog számszerü legyen; ezért a lélekben a szám a legföbb mintája a Teremtőnek, és a dolgokban a legfőbb nyom, amely a bölcsességhez vezet. [10:364-365]

Umberto Eco így összegzi: „Minden középkori értekezés, amelyet a képzőművészetről írtak - Athosz-hegyi szerzetesek által írt bizánciaktól egészen Cennini Traktátusáig-, feltárja a képzőmúvészetnek azt a törekvését, hogy a zenével azonos matematikai szintre kerüljön. E szövegek révén a matematikai elgondolások gyakorlati kánonokká váltak. Képlékeny szabályokról van szó, amelyeket kiragadtak kozmológiai és filozófiai összefüggésükből, de amelyeket mégis összetartanak az ízlés láthatatlan áramlatai." [11:84-85]

\section{Középarányosok szerepe az épí- tészetben - a megépített ará- nyok}

A középarányosok és az arányosság felvázolt jelentése már a görög templomépíté- szetben is konkrét alakot öltött. Jelen dolgozatban azonban a belső tér arányaiban mint az építészet egyik alaptulajdonságában kívánom bemutatni a szerepüket.

\subsection{Vitruvius átriumos római lakó- házának térarány rendszere - az elméleti minta}

$\mathrm{Az}$ átriumos római lakóház építésével kapcsolatban Vitruvius [12:170-172] normatív egységekben határozza meg térarányrendszerét.

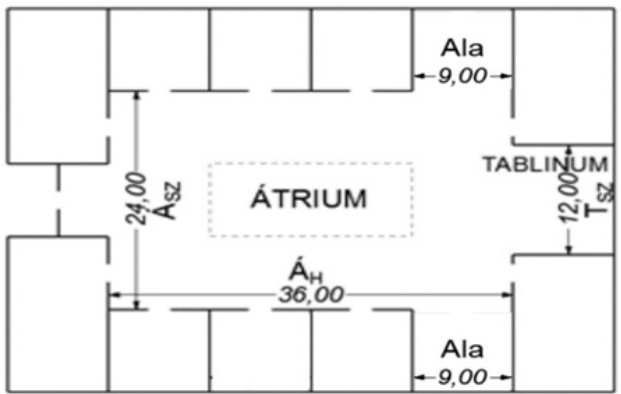

9. ábra. Az átriumos római lakóház sematikus rajza, a föbb helyiségekkel: átrium, tablinum és alák

A ház arányait táblázat formájába lehet rendezni. Ki lehet fejezni valamennyi javasolt arányt az átrium szélességével. Ha az átrium szélessége 24 egység, a 3. táblázat a következő értékek szerint alakul:

Püthagoraszi középarányosok és az arányosság fent leírt fogalmának segítségével meghatároztam egy modellt és eljárást, amivel Vitruvius térarányrendszerének fontos elemeit középarányosokkal elő lehet állítani. 
3. táblázat. Vitruvius római átriumos lakóházának térarányai

\begin{tabular}{|c|c|c|c|c|c|c|c|c|c|c|}
\hline \multicolumn{6}{|l|}{ Átrium } & \multicolumn{5}{|c|}{ Tablinum } \\
\hline \multirow[t]{2}{*}{ Variáns } & \multicolumn{2}{|l|}{ Magasság } & \multicolumn{2}{|c|}{ Hosszúság $\left(\hat{A}_{\mathrm{H}}\right)$} & \multirow{2}{*}{\begin{tabular}{|l|} 
Szélesség $\left(\hat{A}_{\mathrm{sz}}\right)$ \\
24,000
\end{tabular}} & \multirow{2}{*}{\begin{tabular}{|l|} 
Variáns \\
$T_{1}$ \\
\end{tabular}} & \multicolumn{2}{|c|}{ Szélesség $\left(\mathrm{T}_{\mathrm{sz}}\right)$} & \multicolumn{2}{|c|}{ Magasság $9 / 8^{*} T_{\mathrm{sz}}$} \\
\hline & \multicolumn{2}{|l|}{$3 / 4 * \dot{A}_{\mathrm{sz}}$} & $5 / 3 * \dot{A}_{\mathrm{sz}}$ & 40,000 & & & \multicolumn{2}{|c|}{\begin{tabular}{|l|l}
$2 / 3 * \dot{A}_{\mathrm{sz}}$ & 16,000 \\
\end{tabular}} & \multicolumn{2}{|c|}{\begin{tabular}{|l|l}
$3 / 4 * \dot{A}_{\mathrm{sz}}$ & 18,000
\end{tabular}} \\
\hline $\mathrm{A}_{2}$ & $3 / 4 * \dot{A}_{\mathrm{sz}}$ & 18,000 & $3 / 2 * \dot{A}_{\mathrm{sz}}$ & 36,000 & 24,000 & $\mathrm{~T}_{2}$ & $1 / 2 * \dot{A}_{\mathrm{sz}}$ & 12,000 & $9 / 16 * \hat{A}_{\mathrm{sz}}$ & 13,500 \\
\hline $\mathrm{A}_{3}$ & $3 / 4 * \hat{A}_{\mathrm{sz}}$ & 18,000 & $\sqrt{ } 2 * \dot{A}_{\mathrm{sz}}$ & 33,941 & 24,000 & $\mathrm{~T}_{3}$ & $2 / 5 * \hat{A}_{\mathrm{sz}}$ & 9,600 & $9 / 20 * \hat{A}_{\mathrm{sz}}$ & 10,800 \\
\hline \multicolumn{11}{|c|}{ Ala szélesség } \\
\hline \multicolumn{2}{|c|}{ Ala variáns } & \multicolumn{3}{|c|}{$\hat{\mathbf{A}}_{1} \quad\left[\hat{A}_{\mathrm{H}}=40,000\right]$} & \multicolumn{2}{|c|}{$\dot{A}_{2} \quad\left[\dot{A}_{\mathrm{H}}=36,000\right]$} & & \multicolumn{3}{|c|}{$\hat{\mathbf{A}}_{3} \quad\left[\hat{A}_{\mathrm{H}}=39,941\right]$} \\
\hline $1 / 3 * \hat{A}_{\mathrm{H}}$ & $1 / 3 * \dot{A}_{H}$ & \multicolumn{2}{|c|}{$5 / 9 * \hat{A}_{\mathrm{sz}}$} & 13,333 & $1 / 2 * \hat{A}_{\mathrm{sz}}$ & \multicolumn{2}{|l|}{12,000} & $\sqrt{2} / 3 * \dot{A}_{\mathrm{sz}}$ & \multicolumn{2}{|c|}{11,314} \\
\hline $2 / 7 * \hat{A}_{\mathrm{H}}$ & $1 / 3,5^{*} \hat{A}_{\mathrm{H}}$ & \multicolumn{2}{|c|}{$10 / 21 * \dot{A}_{\mathrm{sz}}$} & 11,429 & $3 / 7 * \dot{A}_{\mathrm{sz}}$ & \multicolumn{2}{|l|}{10,286} & \multicolumn{3}{|c|}{\begin{tabular}{|l|l|}
$2 \sqrt{ } 2 / 7 * \hat{A}_{\mathrm{sz}}$ & 9,697 \\
\end{tabular}} \\
\hline $1 / 4 * \hat{A}_{\mathrm{H}}$ & $1 / 4 * \hat{A}_{H}$ & \multicolumn{2}{|c|}{$5 / 12 * \dot{A}_{\mathrm{sz}}$} & 10,000 & $3 / 8 * \dot{A}_{\mathrm{sz}}$ & \multicolumn{2}{|l|}{9,000} & $\sqrt{\sqrt{2} / 4 * \dot{A}_{\mathrm{sz}}}$ & \multicolumn{2}{|l|}{8,485} \\
\hline $2 / 9 * \dot{A}_{H}$ & $1 / 4,5 * \hat{A}_{\mathrm{H}}$ & \multicolumn{2}{|c|}{$10 / 27 * \hat{A}_{\mathrm{sz}}$} & 8,889 & $1 / 3 * \dot{A}_{\mathrm{sz}}$ & \multicolumn{2}{|l|}{8,000} & \multicolumn{3}{|c|}{\begin{tabular}{l|l}
$2 \sqrt{ } 2 / 9 * \hat{A}_{\mathrm{sz}}$ & 7,542 \\
\end{tabular}} \\
\hline $1 / 5 * \dot{A}_{\mathrm{H}}$ & $1 / 5 * \hat{A}_{H}$ & \multicolumn{2}{|c|}{$1 / 3 * \dot{A}_{\mathrm{sz}}$} & 8,000 & $3 / 10 * \AA_{\mathrm{sz}}$ & \multicolumn{2}{|l|}{7,200} & $\sqrt{2} / 5^{*} \hat{A}_{\mathrm{sz}}$ & 6,788 & \\
\hline
\end{tabular}

A modell felépítése:

1. Legyen a kezdeti szakasz AB, ahol $A(a)$ és $B(b), a=x$ és $b=3 x$, ahol $x=6$. $\mathrm{AB}=2 \mathrm{x}$.

2. Felossztjuk $\mathrm{AB}$-t, így nyerjük az $\mathrm{I}_{4}: 1 \mathrm{x}-$ $2 \mathrm{x} ; \mathrm{I}_{1}: 1 \mathrm{x}-1,5 \mathrm{x} ; 1,5 \mathrm{x}-2 \mathrm{x} ; 2 \mathrm{x}-3 \mathrm{x} ; 1,5 \mathrm{x}-$ $3 \mathrm{x} ; 1 \mathrm{x}-3 \mathrm{x}$ arány szerint különböző szakaszokat.
3. Kvóciensnek $k=(a+b) / 2 a=2-t$ választva kiterjesztjük az 1x-2x intervallumot, így kapjuk a $2 \mathrm{x}-4 \mathrm{x}$ és $4 \mathrm{x}-8 \mathrm{x}$ intervallumokat, illetve az 1x-1,5x-et amiből kapjuk a 2x-3x-et, illetve kvóciensnek $\mathrm{k}=2 \mathrm{~b} /(\mathrm{a}+\mathrm{b})=1,5-\mathrm{t}$ választva $1 \mathrm{x}-2 \mathrm{x}$-böl $1,5 \mathrm{x}-3 \mathrm{x}$-et.

4. Valamennyi szakaszban elhelyezzük a középarányosokat.

4. táblázat. Vitruvius átriumos lakóházának belső térarányait leiró modell

\begin{tabular}{|c|c|c|c|c|c|c|c|c|c|c|c|}
\hline & & elosztás & & & & & özéparány & os rends & zer & & \\
\hline & & & Inter & rvallum & $\mathrm{u}$ & $\mathrm{V}$ & $\mathrm{M} 1(\mathrm{u}, \mathrm{v})$ & M2 $(\mathrm{u}, \mathrm{v})$ & M3 $(\mathrm{u}, \mathrm{v})$ & $\mathrm{M} 4(\mathrm{u}, \mathrm{v})$ & M11 (u,v) \\
\hline & jzépa & ányos rendszer & I4 & $1 x-2 x$ & 6,000 & 12,000 & 9,000 & 8,485 & 8,000 & 10,000 & 8,000 \\
\hline & & & I1 & $1 x-1.5 x$ & 6,000 & 9,000 & 7,500 & 7,348 & 7,200 & 7,800 & 6,750 \\
\hline $\mathrm{X}$ & $\mathrm{x}$ & & I2 & $1.5 x-2 x$ & 9,000 & 12,000 & 10,500 & 10,392 & 10,286 & 10,714 & 9,600 \\
\hline $\mathrm{Y}$ & $3 x$ & & I6 & $1 x-3 x$ & 6,000 & 18,000 & 12,000 & 10,392 & 9,000 & 15,000 & 10,800 \\
\hline M1 $(\mathrm{X}, \mathrm{Y})$ & $2 x$ & $\mathbf{M}_{3}$ & I3 & $2 x-3 x$ & 12,000 & 18,000 & 15,000 & 14,697 & 14,400 & 15,600 & 13,500 \\
\hline M3 $(X, Y)$ & $1,5 \mathrm{x}$ & & I5 & $1,5 x-3 x$ & 9,000 & 18,000 & 13,500 & 12,728 & 12,000 & 15,000 & 12,000 \\
\hline & & & & Aránylá & nc alapú & kiterjes & ztés & & & & \\
\hline Kvóciensne & lek k= & $(\mathrm{a}+\mathrm{b}) / 2 \mathrm{a}=2-\mathrm{t}$ választ- & Inter & rvallum & $\mathrm{u}$ & $\mathrm{v}$ & M1 (u,v) & M2 (u,v) & M3 (u,v) & $\mathrm{M} 4(\mathrm{u}, \mathrm{v})$ & M11 (u,v) \\
\hline $\begin{array}{l}\text { va kiterjesz } \\
\text { vallumot, íg }\end{array}$ & így k & pjuk a $2 * I 4: 2 x-4 x$ és & $4 * \mathrm{I} 4$ & $4|8 x-4 x|$ & 24,000 & 48,000 & 36,000 & 33,941 & 32,000 & 40,000 & 32,000 \\
\hline $4 * I 4: 4 x-8 x$ & $x$ inte & rvallumokat & $2 * I 4$ & $4 \mid 4 x-2 x$ & 12,000 & 24,000 & 18,000 & 16,971 & 16,000 & 20,000 & 16,000 \\
\hline
\end{tabular}


Az így kialakult modellben (4. táblázat) elöttünk áll Vitruvius átriumos házának térarányrendszere, matematikailag helyesen eltérések nélkül (átrium-tablinum és egyes alák esetében).

Ez indirekt módon arra enged következtetni, hogy Vitruvius mesteri módon, a püthagoraszi középarányosok segítségével egy világképet (Platón világlelke alapján) szerkesztett vagy komponált, melyet közérthetően jó mérnök módjára mindenkinek elérhetően, normatívan és számszerüen összegzett. A lakóház terének belső méreteit, arányaiban a világot rendező szabályosságok szerint (középarányosok) határozta meg.

\subsection{Jezsuita barokk templomok térarányai - püthagoraszi kö- zéparányosok}

A középkor folyamán, majd később is a humanizmus korában, az arányosság ideája tovább élt, és mint a szépség mérhető tulajdonsága, ahogy Umberto Eco megfogalmazta, az alkotó müvészetek gondolkodásában igen fontos szerepet játszott.

Meglátásom szerint nemcsak a gondolatvilágban, hanem igen konkrétan számszerüen is alkalmazták. A számos építészeti traktátus említi a fenti középarányosok közül az első hármat, ám egyik sem foglalja őket olyan rendszerbe ahogy azt Vitruvius tette. A jezsuita barokk építészet megjelenésével azonban a templomok belső terének hasonló arányrendszerét lehet a megépült és tervezett templomterekben kimutatni. Ennek példája az Il Gesu templom Rómában, melyet minden barokk templom elöképének is lehet tekinteni.

A belső tér meghatározó méreteiről észrevettem, hogy középarányosok segítségével kifejezhetőek a fóhajó szélességével, ugyanúgy mint Vitruvius átriumos római lakóházának méretei az átriumszélességgel. A jezsuita barokk templom meghatározó méretei a belső terek legnagyobb kiterjedé- sei: szélesség, hosszúság magassák, a különböző térrészekben és összességében is.

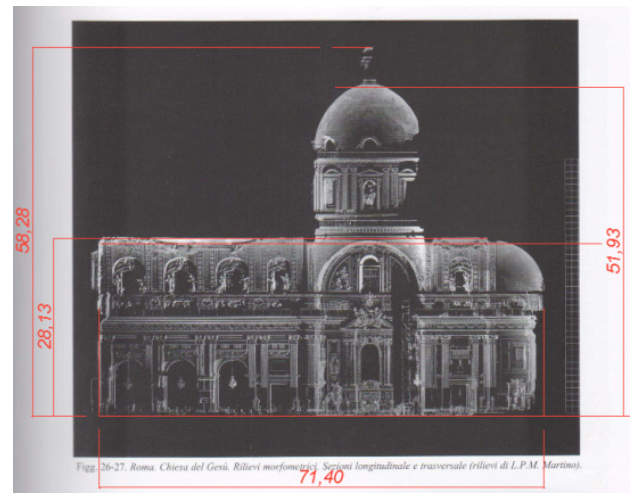

10. ábra. Il Gesu templom, Róma, hosszmetszet (Martino 2009-es 3D-s lézeres mérése) [13]

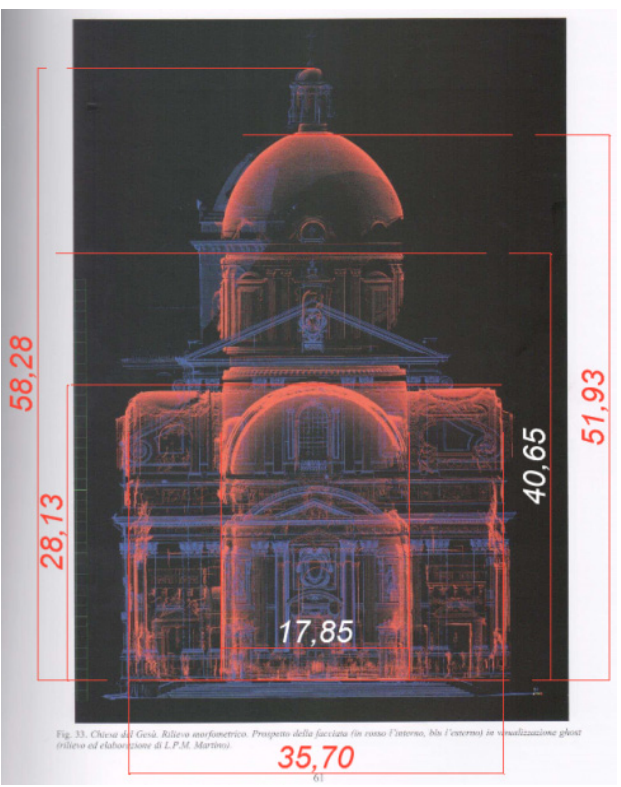

11. ábra. Il Gesu templom, Róma, alaprajz (Martino 2009-es 3D-s lézeres mérése) [13]

A méreteket (felmérés és számított) az 5. táblázatban foglaltam össze. A számított méreteket az 6. táblázat szerint számítottam ki. 
5. táblázat. Az Il Gesu belsőterének mért és számitott meghatározó méretei

\begin{tabular}{|c|c|c|c|c|c|c|}
\hline nr. & Meghatározó méret & Felmérés & $\begin{array}{c}\text { Számított } \\
\text { méret }\end{array}$ & $\begin{array}{c}\text { Közép- } \\
\text { arányos }\end{array}$ & $\begin{array}{c}\text { Aritmetikai } \\
\text { különbség }\end{array}$ & $\begin{array}{c}\text { Százalék- } \\
\text { os eltérés }\end{array}$ \\
\hline 1 & Kereszthajó szélessége & 35,71 & $\mathbf{3 5 , 7 0}$ & M2,M5 & 0,01 & $0,03 \%$ \\
\hline 2 & Teljes szélesség & 33,92 & 33,92 & M8 & 0,01 & $0,01 \%$ \\
\hline 3 & Hajó magasság & 28,13 & 28,22 & M2,M5 & 0,09 & $0,33 \%$ \\
\hline 4 & Kupola aljának magassága & 40,65 & 40,80 & M11 & 0,15 & $0,37 \%$ \\
\hline 5 & Kupola teljes magasága & 51,93 & 51,93 & M11 & 0,00 & $0,01 \%$ \\
\hline 6 & Teljes magasság & 58,28 & 58,01 & M8 & 0,27 & $0,46 \%$ \\
\hline $\mathrm{x}$ & Hajó szélesség & 17,85 & 17,85 & & - & $0,00 \%$ \\
\hline $\mathrm{y}$ & Teljes belsö hosszúság & 71,40 & 71,40 & & - & $0,00 \%$ \\
\hline
\end{tabular}

6. táblázat. Az Il Gesu meghatározó belsőtere méreteinek számitása

\begin{tabular}{|c|c|c|c|c|c|c|}
\hline \multicolumn{2}{|r|}{ Középarány } & \multicolumn{5}{|c|}{ Il Gesu - Roma } \\
\hline \multirow{3}{*}{ 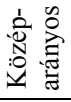 } & Lépés & I & II & III & IV & \multirow{3}{*}{$\begin{array}{l}\text { Közép- } \\
\text { arányos }\end{array}$} \\
\hline & $\mathrm{X}$ & 17,85 & 44,63 & 17,85 & & \\
\hline & $\mathrm{Y}$ & 71,40 & 71,40 & 44,63 & & \\
\hline M1 & $\mathrm{m}=\frac{\mathrm{x}+\mathrm{y}}{2}$ & 44,63 & 58,01 & 31,24 & & M1 \\
\hline M2 & $\mathrm{m}=\sqrt{\mathrm{x} \cdot \mathrm{y}}$ & 35,70 & 56,45 & 28,22 & & M2 \\
\hline M5 & $\mathrm{m}=\frac{\mathrm{y}-\mathrm{x}}{2}+\sqrt{\left(\frac{\mathrm{y}-\mathrm{x}}{2}\right)^{2}+\mathrm{x}^{2}}$ & 58,95 & 59,98 & 35,70 & & M5 \\
\hline M8 & $m=x+\frac{(y-x)^{2}}{y}$ & 58,01 & 54,67 & 33,92 & & M8 \\
\hline M11 & $\mathrm{m}=\frac{\mathrm{y}^{2}}{2 \cdot \mathrm{y}-\mathrm{x}}$ & 40,80 & 51,93 & 27,89 & & M11 \\
\hline
\end{tabular}

\section{Következtetések}

A középarányosok „felfedezése” és megismerése az európai kultúrának a hajnalán történt, és központi szerepet játszott az akkori gondolkodásban. A középarányosok tulajdonságait a tapasztalattól az empírikus gyakorlaton át a matematikai absztrakcióig feltárták az ókori bölcsek, majd Platón emelte rendező elvvé a világban. Az így megalkotott idearendszer a zenében és később az építészetben törekedtek megvalósítani a különbözö müvészetek.

$\mathrm{Az}$ eddigi vélekedésekkel ellentétben középarányos rendzser mutatható ki Vitruvius elméleti munkásságában, ami a későbbi korok építészetére döntő hatást gyakorolt.
Középarányosok felhasználása mutatható ki a jezsuita barokk építészetben is, melynek alappéldája a római Il Gesu templom, ahogy ezt a jelen dolgozatban bemutattam, vagy négy erdélyi jezsuita templom esetében, ahogy ezt doktori disszertációmban igazoltam [14].

Meglátásom szerint a középarányosok tanulmányázása számos olyan kérdésre és összefüggésre ad sokkal egyszerübb és átfogóbb magyarázatot, amit eddig csak izoláltan vagy körülményesen ismert (vagy nem ismert) az élő tudomány, különösen az építészet és építészettörténet, -elmélet.

$\mathrm{Az}$ ujdonság nem új összefüggések megtalálásában rejlik, hanem a régi gondolat-gyakorlat-eszmevilágot átfogó egységes gondolkodás újrafelismerésében és matematkai összefüggéseinek, tulajdonságainak 
ismertetésében. Az elfeledett eredet bemutatásában.

A dolgozat újdonságai az építészetelmélet és -történet egy teljesen új szemléletének lehet a kindulópontja. A felvetett kérdések, válaszok és összefüggések alapján egy középarányosokon alapuló építészettörténeti fejlődésvonalat lehet kialakítani.

\section{Szakirodalmi hivatkozások}

[1] Platón: Platón összes müvei harmadik kötet. Európa Kiadó, Budapest, 1984. 332, 328-329, 329, 331-333, 333-339

[2] Sain Márton: Nincs királyi út! Gondolat, Budapest, 1986. 23, 23, 78-80, 82, 81-82, 101, 106, 114, 252,

[3] Boyer, Carl B., Uta C. Merzbach: A History of Mathematics. John Wiley \& Sons, New York [etc.], 1991, 28, 27, 56.

[4] Hischer, H. Viertausend Jahre Mittelwertbildung. Eine fundamentale Idee der Mathematik und didaktische Implikationen. In: Mathematica didactica 25 (2002)2, 351. - Als „Preprint Nr. 98” in der Preprint-Reihe der Fachrichtung Mathematik der Universität des Saarlandes erschienen, dort eingereicht am $04 . \quad$ November 2003. http://hischer.de/uds/forsch/publikat/hischer/ (12/12/2011), 15-17, 25

[5] Eves, Howard Whitley: Great moments in mathematics (before 1650). Mathematical Association of America, [Washington, D.C.], 1983. 11-13.

[6] Taylor, A.E: Platón. Osiris Kiadó, Budapest, 1997. 617, 617, 617, 695 .
[7] Cantor, M.: Vorlesungen über Geschichte der Mathematik Bd. 1, Von den ältesten Zeiten bis zum Jahre 1200 n. Chr. Vorlesungen Über Geschichte Der Mathematik. Teubner, Leipzig, 1894., 226-227, 226.

[8] Nicomachus, Martin Luther D'Ooge, Frank Egleston Robbins, and Louis Charles Karpinski: Introduction to Arithmetic. Macmillan Co, New York, 1926., 283, 283-284, 257-259.

[9] Heath, Thomas Little: A History of Greek Mathematics: Volume 1 From Thales to Euclid. Clarendon Press, Oxford, 1921. 87.

[10] Szent Bonaventura: Itinerarium,c II, 4-6, In: Redl Károly: Az égi és a földi szépröl. Gondolat, Budapest, 1989. 364-365.

[11] Umberto Eco: Müvészet és szépség a középkori esztétikában. Európa Kiadó, Budapest, 2002. 84-85.

[12] Vitruvius: Tíz könyv az épitészetröl. Képzőmüvészeti Kiadó, Budapest, 1988. $170-172$.

[13] Martino, Lorenzo Pio Massimo: La chiesa del Santissimo Nome del Gesù a Roma. Una nuova lettura tra 'ordini nascosti' $e$ proporzioni da rilievi $3 D$. In: Quaderni del Dipartimento Patrimonio Architettonico ed Urbanistico, nr35-36/2009.,47-68.

[14] Orbán, Gy.: Analysis and valorisation of the built heritage of the roman-catholic church of Transylvania within the pilgrimage route "Way of Mary", Doktori dolgozat. Kolozsvári Müszaki Egyetem, Kolozsvár, 2013. 141-201. 